\title{
PROFILE: NAOMI PINNOCK
}

Naomi Pinnock was born in 1979 in Yorkshire, UK. She studied composition with Wolfgang Rihm at the Hochschule für Music Karlsruhe, Harrison Birtwistle at King's College London and with Brian Elias at the Royal Academy of Music in London. With an emphasis on reducing music to its essential elements, her work has been described as 'enigmatic' (a review of Words on the blog 5:4) and as having 'great intensity' (String Quartet no. 2, reviewed in

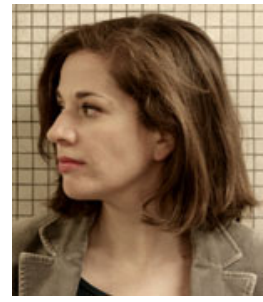

Naomi Pinnock (photo: Amy Newiss) Neue Zeitschrift für Musik).

She has collaborated with groups such as the Arditti Quartet, London Sinfonietta, Neue Vocalsolisten Stuttgart, Schola Heidelberg and Kammerensemble Neue Musik Berlin and with soloists including Frode Haltli, Omar Ebrahim and Rolf Hind. And her work has been performed at various international music festivals such as hcmf//, Wittener Tage für neue Kammermusik, ECLAT Festival Stuttgart, Heidelberger Frühling, Festival Musica in Strasbourg and Spitalfields Festival London. In 2010 she received the Berlin-Rheinsberger Kompositionspreis, in 2012 the Collard Fellowship and in 2013 the Günther-Bialas Kompositionspreis. Naomi is currently collaborating with performance-maker Nic Green and writing a new work for the BBC Scottish Symphony Orchestra, a commission supported by the PRSF Composers' Fund.

Q: What is your earliest significant musical memory?

A: I don't think I can pin that one down, possibly to do with my terrible memory. But I just remember that I always enjoyed making music, singing, playing the violin and piano.

Possibly more significant is that I remember the satisfying feeling of making things and sitting for hours on my own drawing, painting, designing. I don't know that there is anything inherently special about that, but it has been one of the few consistent things in my life - the need to create and the joy I have in it.

Q: When did you know you wanted to be a composer?

A: Not for a long time, certainly not until I'd got into the last year of my bachelors' degree when I was specialising in composing. I mean, I'd enjoyed it up until that point but as a career, I don't remember ever really thinking about it that clearly. I certainly had no idea about what you had to do to make a living from composing.

Apart from the exception of wanting to become a doctor - which started at the age of about 12 and has intermittently come back again over the years - I've always wanted to do something creative. I think I subconsciously began to collect female role models, starting with the artist Gwen John, when I was still at school (thanks to my brilliant art 
teacher Mr Murphy), moving onto the writer Janet Frame and later the artist Rachel Whiteread. They were my inspiration during my student years. Sadly there were no female composers in this 'club' I'd unintentionally formed.

Q: Was your musical education a help or a hindrance?

A: My whole musical education? Well I don't think I would have got very far without any of it, from having recorder lessons from the secretary at my tiny first school to studying with Wolfgang Rihm.

But let's talk about the hindrance part as it pertains to gender because I think we can all agree that even if I do have particular niggles about how I was taught or what was missed, I have been very lucky and privileged to have had the education that I've had. It infuriates me that there is still such a gender imbalance in the classical music world and this is perpetuated by the structures that we hang onto. Over the six years of my tertiary education I was taught by a total of three women (only one, briefly, in composition), two of whom were teaching as part of their postgraduate course. People should go and count how many female-identifying composers there are teaching in the UK. You are not going to need that many fingers.

There weren't any female role models in my 'club' because even if they were around (and I do wish I'd found some earlier - Pauline Oliveros I'm looking at you) I was not exposed to them in the way I was to writers and artists. I see this getting better, I do, I do, and I know so many people are, in different ways, putting themselves and their organisations forward to change. But let's not kid ourselves that there aren't still barriers to female-identifying composers considering studying composition. Or not even considering, how about just being creative and liking music.

Q: Your music seems to me always to have a very clear formal profile. Is this something you consciously seek during the process of composition or is the starting point?

A: Ah yes, form. You can't live with it and you can't live without it. It can become a straitjacket if you're not careful! The best-case scenario is that it's a fluid kind of vessel that shifts sympathetically with the musical material. I'm totally fascinated by form and constantly come back to it during the compositional process. I know composers who find a form, before they begin with sound, and stick to it. I know others who start at the beginning of the piece and work chronologically. I am a juggler, going from micro to macro again and again before I realise I hate it all and start over. It's exhausting!

There are forms that I prefer, I'd say, particularly short blocks or movements. And I've started to prefer endings that aren't closed (is that form?). Sometimes I have a clearer idea about how to organise material much earlier on (I'm thinking of Lines and Spaces) but even then I do an awful lot of swapping around (at least it seems like that to me).

Q: We live in an era in which 'classical' instrumentation, notation, concert halls, and event presentation can all seem terribly old-fashioned. Is this something you think about?

A: Absolutely. I am constantly astounded by the feeling I get sitting in concerts, waiting for them to begin. Who are these people? How did I end up here? Or I get suddenly weirded-out by the rituals performers go through on stage, the standing, the bowing ... oh and don't get me started on the clothes. 
OK then: I was at the Musikhochschule in Munich some years ago where a piece of mine was being presented and the soloist singers came on stage at the end of the concert and it just dawned on me that all the women were wearing floor-length gowns. And I felt suddenly and surprisingly sad that nothing. ever. changes.

I've been getting to know the performance/live art scene a bit over the last year or so and I have to say it's been a refreshing revelation. Equality, diversity, accessibility are simply part of the community and part of the art. It is constantly being paid attention to, at least by the artists I've met, and it's such an integral part of their practice and being a person in the world. And then I go back to my classical world and I start to see just how conservative it all is. But then ... Be the change you want to see, right?

I would disagree that notation is old-fashioned in the same way that writing words down for people to speak is not old-fashioned. New technologies do not negate older ones. I love notation. It's a puzzle really. How do you go from hieroglyphics to sound? No. It's not the notation's fault or the instrumentation's fault (on the whole). We as a community have a lot of catching up to do in how we behave as a group. 